\section{Ks. Wojciech Kamczyk}

Uniwersytet Śląski w Katowicach

wojciech.kamczyk@us.edu.pl

DOI: http://dx.doi.org/10.12775/BPTh.2017.004

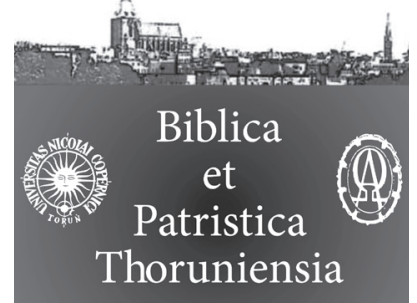

10 (2017) 1: 77-99

ISSN (print) 1689-5150

ISSN (online) 2450-7059

\title{
Pijaństwo jako problem moralny i duszpasterski u św. Augustyna
}

\section{Inebriety as a moral and pastoral problem in St. Augustine}

Streszczenie. Nadużywanie wina (i alkoholu w ogóle), nadmierne ucztowanie i pijaństwo stanowią nie tylko problem moralny, ale i duszpasterski. Biskup Hippony, św. Augustyn, w swoich homiliach i listach podejmował ów problem nie tylko ogólnie, lecz także wskazując szczegółowe zagadnienia i problemy, które dotyczyły jego gminy. Pijaństwo stanowiło element uczt urządzanych przy okazji religijnych obchodów, zaciemniając w ten sposób ich właściwy sens. Do najistotniejszych należało pijaństwo neofitów tuż po przyjęciu sakramentów wtajemniczenia oraz pijackie uczty związane $\mathrm{z}$ obchodami ku czci zmarłych urządzane na ich grobach. Augustyn sprzeciwiał się im, odwołując się do argumentów biblijnych i liturgicznych, zwyczajów Kościoła powszechnego, a także zwykłego, ludzkiego poczucia godności. Starał się korygować wypaczone rozumienie efektów działania alkoholu, przyrównywanych do działania Ducha Świętego. Artykuł ukazuje duszpasterską wrażliwość biskupa, starającego się wprowadzić religijną aktywność wiernych na właściwe tory.

Abstract. The abuse of wine (and alcohol in general), excessive feasting and drunkenness is not only a moral but also a priestly issue. The Bishop of Hippo, St. Augustine, undertook this problem, in his homilies and letters, not only broadly, but designating the specific issues and problems that concern his municipality. Inebriety was a part of arranged feasts on the occasion of religious celebrations, overshadowing their true meaning. The most important issue was the drunkenness of neophytes immediately after the obtainment of the sacraments of initiation and drunken feasts associated with the celebrations in honor of the dead at their graves. Augustine opposed them referring to the biblical arguments and liturgical traditions of the universal Church, and ordinary human dignity. He tried to reclaim the distorted apprehension of the effects of alcohol abusing, assimilated to the action of the Holy Spirit. The article presents the pastoral sensitivity of the bishop who tries to establish the religious activity of the faithful on the right track.

Słowa kluczowe: św. Augustyn; duszpasterstwo; pijaństwo; sakramenty wtajemniczenia; obchody ku czci zmarłych; Duch Święty.

Keywords: St. Augustine; ministry; drunkenness; the sacraments of initiation; the celebration in honor of the dead; the Holy Spirit. 
Dijaństwo stanowiło i stanowi do dziś poważny problem społeczny. Czasem jest on uświadomiony, co pozwala na podjęcie odpowiedniej prewencji, czasem bywa ukryty, co prowadzi do wielu powikłań i komplikacji. Chrześcijanie jako społeczność religijna także nie byli od niego zupełnie wolni. Stanowił on wyzwanie nie tylko moralne, ale i duszpasterskie. Związany z różnymi przejawami ludzkiej aktywności, pracy, rozrywki, życia rodzinnego nie omijał sfery sakralnej, gdzie alkohol odgrywał również pewną rolę. Musiano zmierzyć się z kwestią wykorzystania i spożywania alkoholu, tak w związku z życiem religijnym, jak i prywatnym. Święty Augustyn, biskup Hippony, wytrawny duszpasterz, dostrzegał w powierzonej mu wspólnocie problemy związane $\mathrm{z}$ nieumiarkowanym spożywaniem wina ${ }^{1}$. W niniejszym artykule chciałbym zbadać, z jakimi najistotniejszymi problemami związanymi z pijaństwem borykał się Kościół w Hipponie, na ile powiązane były one z religijnością wiernych oraz w jaki sposób duszpasterz starał się przeciwdziałać niegodnym praktykom i uzasadniać teologicznie swoje stanowisko. Podstawą analizy będą homilie i listy biskupa Augustyna. Inne pisma bądź autorzy przywołani zostaną jedynie w celach lepszego zobrazowania sytuacji i problemów poruszanych przez niego.

\section{Moralna ocena pijaństwa}

Wino stanowiło jeden z podstawowych napojów, jakimi raczyli się starożytni. Było podstawowym składnikiem uczt, tych skromniejszych, w jakich uczestniczyli biedacy, jak i tych bardziej wystawnych, organizowanych przez bogatych obywateli. Afryka Północna, słynąca z produkcji tego trunku, także korzystała z jego dobrodziejstw ${ }^{2}$.

Spożywanie wina samo w sobie nie bywało potępiane, zwłaszcza że trudno było o alternatywę. Moralna ocena Augustyna koncentrowała się więc nie tyle na samym napoju, ile na sposobie jego używania i łączenia z życiem religijnym. W czasie jednego z kazań wyjaśniających ideę postu, mówił:

Pijaństwa i nietrzeźwości powinno się przez wszystkie dni unikać - przez te zaś dni odstąp od posiłków, z których należy zrezygnować3.

1 Por. A.G. Hamman, Życie codzienne w Afryce Pótnocnej, s. 77.

2 Por. E. Bugaj, Starożytni Rzymianie i ich uczty, s. 147-148; A.G. Hamman, Życie codzienne w Afryce Północnej, s. 77.

3 Sermo 207, 2, NBA 32/1, 150: „Crapula et ebrietas etiam per dies caeteros devitanda: per hos autem dies etiam concessa prandia removenda”. 
Stwierdzenie to, zwłaszcza przy okazji nauczania o właściwym podejmowaniu postu i wyrzeczeń, powtarza wielokrotnie ${ }^{4}$. Nie neguje samego spożywania wina, potępia jednak jego nadużywanie, co z pewnością nie było rzadkie we współczesnej mu społeczności ${ }^{5}$. Nie wystarczyły jej zapewne te krótkie wskazania biskupa, gdyż ten nieraz pogłębiał swoje nauczanie i solidnie motywował właściwe postawy chrześcijańskie względem spożywania alkoholu. Biskup nauczał, że upijanie się jest zachowaniem nagannym zawsze, a nie jedynie w pewnych okresach roku. Umiarkowanie z kolei jest postawą wymaganą od wszystkich chrześcijan ${ }^{6}$. To rys pozwalający rozpoznać ich wśród pogan ${ }^{7}$. Całkowita abstynencja zaś może stać się formą pokutnego przeżywania tajemnic wiary ${ }^{8}$. Nie powinna jednak przybierać dwuznacznych form, polegających na zastępowaniu wina innymi, bardziej wyszukanymi napojami ${ }^{9}$.

Kaznodzieja z Hippony nie prowadzi szczegółowej klasyfikacji występków związanych z pijaństwem. Widzi jednak w nim niebezpieczeństwo wiążące się z jego zbagatelizowaniem:

Zwróćcie uwagę, co mówi Pismo, i zobaczcie, w jaki sposób powinniście żyć. Czyż nie potępia [ono] grzechu pijaństwa? Ma w nadmiarze tego grzechu i gardzi nim. Serce pijaków utraciło już poczucie [grzechu], nie czuje bólu, ponieważ nie ma zbawienia. Kiedy jeszcze walczy i boli, i prowadzi ku zdrowiu, jest w nim jeszcze nadzieja uzdrowienia. Kiedy zaś jest drażnione, jest ranione, bądź jest związywane i nie boli, ma być przeznaczone śmierci i odcięte od ciała ${ }^{10}$.

Pijaństwo należy do tego rodzaju grzechów, które prowadzą do grzesznego przyzwyczajenia. Cechą charakterystyczną takiego stanu jest brak odczuwania

4 Por. Sermo 207, 2, NBA 32/1, 150; Sermo 205, 2, NBA 32/1, 138-140; Sermo 206, 3, NBA $32 / 1,146$.

5 Por. Sermo 198, 1, NBA 32/1, 92.

6 Por. Sermo 205, 2, NBA 32/1, 138.

7 Por. Sermo 198, 1, NBA 32/1, 92.

8 Por. Sermo 206, 3, NBA 32/1, 146.

9 Praktyki te krytykował Augustyn, ganiąc tych, którzy choć nie spożywali wina i nie upijali się, to jednak dogadzali sobie innymi napojami czy wyszukanymi likierami; por. Sermo 205, 2, NBA 32/1, 138-140.

10 Sermo 17, 3, NBA 29, 332-334: „Attendite quae dicat Scriptura, et ibi videte quemadmodum vivere debeatis. Quis non contemnat ebriositatis peccatum? Abundat tale peccatum, et contemnitur. Iam cor ebriosorum perdidit sensum, non habet dolorem, quia nec salutem. Quando aliquid pungitur et dolet, aut sanum est aut est in illo spes aliqua sanitatis. Quando autem tangitur, pungitur vel ligatur nec dolet, pro mortuo habendum est, aut de corpore praecidendum". 
problemu, niedostrzeganie go. Wiąże się to z utratą świadomości zła, a także $\mathrm{z}$ utratą potrzeby zbawienia.

Ocena Augustyna jest bardzo przenikliwa. Opierała się zapewne na obserwacji codziennego życia tych, którzy nadużywali wina: „serce pijaków” traciło poczucie grzechu i nie widziało zła tego postępowania. Sformułowanie biskupa można odnieść do pojęcia sumienia, bo mówi tu o rodzaju świadomości zła i grzechu. „Serce pijaków” nie dostrzega już zła, jakie kryje się za zgubną praktyką. Serce odczuwające ból, oznacza być może swego rodzaju wyrzuty sumienia, świadomość zła własnego postępowania i pewien brak zgody na taki stan rzeczy. Wiąże się z nim pragnienie zdrowia i nadzieja zbawienia, które skłaniają do nawrócenia. „Serce pijaków” jednak niezdolne jest do odczuwania bólu, nie widzi zła w powziętych praktykach, nie jest więc skore do zmiany. Autor mówi, że jest „zmierzającym do śmierci” i „mającym być odciętym”. Być może chce w ten sposób zasugerować słuchaczom, że oddający się pijaństwu, powinni być odcięci od "ciała”, co stanowi aluzję do Pawłowej nauki o Kościele ${ }^{11}$. Jest to przestroga przed wykluczeniem ze zgromadzenia wiernych i zapewne to ten ostatni argument był dla audytorium najbardziej przekonujący.

Pragnąc pobudzić do właściwych zachowań, Augustyn pisał:

Niech czystość małżeńska ozdobi twoje obyczaje, niech je ozdobi trzeźwość i wstrzemięźliwość. Haniebnym jest, aby tam, gdzie nie zwycięża człowiek, zwyciężała żądza, i aby był powalony przez wino ten, kto nie został zwyciężony mieczem $^{12}$.

Autor dostrzegał w pijaństwie problem dotykający godności człowieka i jego honoru. Odwołał się przy tym do kwestii militarnych, porównując zwycięstwo nad własnymi zachciankami czy skłonnościami do zwycięstwa w walce. Wskazał, że ten, kto zwycięża orężem, powinien być zdolny do zwycięstwa nad sobą. Wstrzemięźliwość i trzeźwość są cnotami stanowiącymi ozdobę życia człowieka - chrześcijanina.

Swojemu adresatowi Augustyn wskazuje na ośmieszające i dyskredytujące skutki pijaństwa. Nawet człowieka najmężniejszego i cnotliwego może ono doprowadzić do postaw i zachowań nielicujących z jego godnością.

11 Por. W. Staniszewski, Kościół jako mistyczne Ciało Chrystusa, s. 17-20; T.J. van Bavel, Église, s. 494-496.

12 Epistula 189, 7, NBA 23, 200: „Ornet mores tuos pudicitia coniugalis, ornet sobrietas et frugalitas: valde enim turpe est, ut quem non vincit homo, vincat libido; et obruatur vino, qui non vincitur ferro"; tłum. J. Krzemiński, w: Antologia listu starochrześcijańskiego, t. 1, s. 141. 
Wtedy oddałem Księgę Wyjścia i w mocnych barwach, na ile czas pozwalał, przedstawiając występek pijaństwa, wziąłem listy apostoła Pawła i pokazałem, do jakich grzechów zalicza on pijaństwo: „Gdyby ktoś się bratem waszym mienił, a byłby rozpustnikiem albo bałwochwalcą, albo chciwcem, albo oszczercą, albo pijakiem lub zdziercą, z takim nawet nie siadajcie wspólnie do posiłku” (1 Kor 5,11). Opłakując ten występek, wskazałem na wielkie niebezpieczeństwo spożywania posiłków nawet z tymi, którzy się w domach upijają ${ }^{13}$.

Pijaństwo należy postawić, zgodnie z myślą św. Pawła (1 Kor 5,11), na równi z grzechami cudzołóstwa, bałwochwalstwa, chciwości, oszczerstwa i zdzierstwa. Choć argumentacja Augustyna opiera się na myśli Pawłowej, to należy zauważyć, że dwa pierwsze z wymienionych grzechów traktowane były w Kościele starożytnym jako „peccata mortifera” 14 . Wiązała się z nimi konieczność długotrwałej publicznej pokuty. Stanowiła więc możliwość poważnej uciążliwości w codziennym życiu chrześcijanina, który pragnął żyć pojednany z Bogiem. Druga grupa wymienionych grzechów zawiera postawy, mogące być szczególnie rażące dla słuchaczy i odbiorców Augustyna. Zestawienie z nimi pijaństwa, które mogło cieszyć się pewną pobłażliwością ze strony wiernych, było zabiegiem mającym oddziaływać na samą ocenę nadużywania wina. Autor podkreślał też aspekt doraźnej „kary”, jaka winna wiązać się z pijaństwem - wierzący $\mathrm{z}$ takimi osobami nie powinni w ogóle zasiadać do wspólnego stołu. W innym podobnym Pawłowym zestawieniu przytaczanym przez Augustyna pobrzmiewa groźba wykluczenia z Królestwa Bożego. Autor wiązał ją z zamknięciem wewnętrznej świątyni serca, między innymi przez grzech pijaństwa, na obecność Boga. Pijaństwo nie jest owocem Ducha, lecz uczynkiem ciemności ${ }^{15}$.

Należy zatem wyraźnie zaznaczyć, że samo spożywanie wina, bądź szerzej alkoholu, nie stanowiło dla biskupa problemu od strony moralnej. Dopiero jego nadużywanie uznawane było za poważne wykroczenie o randze grzechu śmiertelnego. Niedostateczna świadomość wiernych w tym względzie skłaniała biskupa do dbałości o odpowiednią wrażliwość słuchaczy. Przestrzegał zwłasz-

13 Epistula 29, 5, NBA 21, 186: „Tunc reddito Exodi codice, crimen ebrietatis, quantum tempus sinebat, exaggerans, sumpsi apostolum Paulum, et inter quae peccata posita esset obstendi, legens illum locum: «Si quis frater nominetur aut fornicator, aut idolis serviens, aut avarus, aut maledicus, aut ebriosus, aut rapax; cum eiusmodi nec cibum sumere» (1 Kor 5,11); ingemiscendo admonens cum quanto periculo convivaremur cum eis qui vel in domibus inebriarentur", tłum. W. Eborowicz, s. 217.

14 Por. A.G. Fitzgerald, Pénitence, s. 1118; A.M. La Bonnardière, Pénitence et reconciliation des pénitents, s. 256.

15 Por. Epistula 29, 5-6, NBA 21, 186-188. 
cza przed nawykiem pijaństwa, które osłabiało wolę i świadomość zła, prowadząc do utrwalania zachowań i grzechu.

\section{Pijaństwo związane z obchodami Paschy}

Ogólne uwagi Augustyna dotyczące pijaństwa, nie pojawiały się w jego nauczaniu spontanicznie. Najczęściej związane były z konkretnymi niepożądanymi sytuacjami, jakie miały miejsce $\mathrm{w}$ gminie chrześcijańskiej. Jednym $\mathrm{z}$ powtarzających się problemów, było niewłaściwe świętowanie chrztu, kiedy to nowo ochrzczeni, a prawdopodobnie także i część wiernych, po całonocnym czuwaniu, modlitwach i przystąpieniu do sakramentów, wracali do domów ucztować, często się przy tym upijając ${ }^{16}$. Na kolejne popołudniowe spotkanie przychodzili nietrzeźwi, nad czym bolał obserwujący ich duszpasterz:

Nie chciejcie wychodzić stąd trzeźwymi, a wracać pijanymi: i po południu będziemy was widziećc ${ }^{17}$.

Zwyczaj ten musiał być mocno zakorzeniony wśród wiernych i przekazywany poza oficjalnym nauczaniem. Zainteresowani nie kryli się zapewne zbyt mocno ze swoimi planami, a także samymi efektami ucztowania, skoro biskup w tak bezpośredni sposób, uprzedzając wydarzenia, napominał słuchaczy. Uzasadniając swoje stanowisko, wskazując niekonsekwencję takich planów, nawiązując do przeżytej właśnie liturgii, tłumaczył:

Ta nasza pieśn jest wspomnieniem zobowiązania do dobrego życia. Kiedy wszyscy mówimy harmonijnym głosem, radosnym duchem, zgodnym sercem: To jest dzień, który Pan uczynił, zgadzajmy się z naszym głosem, niech nasz język nie mówi przeciw nam świadectwa [oskarżenia]. Zamierzając dzisiaj się upić, mówisz: To jest dzień, który Pan uczynił; nie boisz się, że mógłby tobie odpowiedzieć: tego

16 W niektórych regionach Kościoła istniał zwyczaj, krytykowany przez duszpasterzy, by podobne uczty robić w kościele. Zwykle nie miały one miejsca w tej bazylice, w której odbywały się celebracje, ale w podmiejskich kościołach. Pijaństwo i ucztowanie było dla niepogłębionej pobożności prostych wiernych przedłużeniem samej celebracji liturgicznej; por. A. Młotek, Postawy i świadectwa, s. 304.

17 Sermo 225, 4, 4, NBA 32/1, 380-382: „Nolite discedere sobrii, et redire ebrii: et post meridiem videbimus vos". 
dnia nie uczynił Pan? I nazywany jest dobrym dniem ten, który uczynił się przez lubieżność i złośliwość dniem złym ${ }^{18}$.

Nauczając w Noc Zmartwychwstania, duszpasterz powoływał się na teologię i symbolikę przeżywanych misteriów. W tym celu porównał pijaństwo do czynów związanych z przebywaniem w ciemności. Od nich właśnie winni odwracać się nowo ochrzczeni. Przypomniały o tym kończące się Noc Paschalna oraz powtarzany psalm: „Oto dzień ustanowiony przez Pana, radujmy się nim i weselmy" (Ps 118,2419). Planując pijaństwo w Dzień Zmartwychwstania, neofici, wyśpiewując słowa Psalmu, wystosowują przeciw sobie oskarżenie. Zaprzeczają przyjętej w chrzcie prawdzie, że stali się Dniem Pańskim, bo pragną pogrążyć się w ciemności pijaństwa. Dlatego w innym miejscu biskup nawoływał:

Unikajcie ciemności. Pijaństwo pochodzi z ciemności ${ }^{20}$.

Wiążąc pijaństwo z symboliką ciemności, duszpasterz nawiązywał do nauki św. Pawła zawartej w Liście do Efezjan (por. Ef 5,3-14). Przed chrztem neofici znajdowali się w stanie „ciemności”, nie byli oświeceni łaską wiary i sakramentów. Wydarzenia paschalne sprawiły, że stali się „światłością”, „dniem, który Pan uczynił". Śpiewali o tym podczas liturgii. Pijaństwo stanowiło zatem całkowite zaprzeczenie tego, co przeżyli.

Rozwijając ten wątek, kaznodzieja mówił:

Przemawiamy o tym dniu słowami apostolskimi. O dniu, który Pan uczynił, byliście niegdyś ciemnością: teraz zaś [staliście się] światłem w Panu. «Byliście niegdyś ciemnością» - rzekł. Byliście czy nie? Wspomnijcie wasze czyny, czy nie byliście. Zbadajcie wasze sumienia, które je oceniają. Ponieważ więc «byliście niegdyś ciem-

18 Sermo 229b, 1, NBA, 32/1, 416-418: „Ista ergo nostra cantatio, vitae bonae est commemoratio. Quando dicimus omnes voce consona, laeto spiritu, corde concordi: Hic est dies quem fecit Dominus, congruamus sono nostro, ne testimonium contra nos dicat lingua nostra. Inebriaturus te hodie dicis: Hic est dies quem fecit Dominus; non times, ne tibi respondeat: Istum diem non fecit Dominus; et ipse dicitur bonus dies, quem sibi faciat luxuria et nequitia pessimum diem".

19 Tekst Pisma Świętego w tłumaczeniu R. Popowskiego, w: Biblia pierwszego Kościoła, s. 799.

20 Sermo 225, 4, 4, NBA, 32/1, 380-382: „Fugite tenebras. Ebrietas ad tenebras pertinet". 
nością, teraz zaś [staliście się] światłem», nie w was, lecz «w Panu, jako dzieci światłości postępujcie (Ef 5,8)» ${ }^{21}$.

Duszpasterz zachęcał do stawiania sobie pytań i badania swojego sumienia. Liczył na właściwą ocenę sytuacji przez słuchaczy. Prowadzony przez niego wątek światła porównanego z ciemnością miał pozwolić na zobaczenie w chrześcijańskiej perspektywie własnego życia. Służyło temu także przypomnienie faktu dziecięctwa Bożego, które stało się udziałem ochrzczonych.

Dlatego w innym miejscu mówił:

Duch Święty jest i światłem, i napojem. Jeśli odnalazłeś źródło w ciemności, przystąpiłeś do zapalonej pochodni i przyszedłeś do Niego. Nie chciej przystępować do lampy zamiast do źródła światła. On sam ciebie oświeci i do siebie cię zaprowadzi. Jeśli przychodzisz do picia, przystąp i bądź oświecony. «Przystąpcie do Niego, a rozświetli was (Ps 33,6)»; nie chciejcie odchodzić, nie zakrywajcie Pana Boga, wołaj, aby przyszedł do ciebie, potwierdzaj, aby nie odszedł od ciebie. Uczyń synów twych odnowionymi, [uczyń] z maleńkich dojrzałych, lecz nie z dojrzałych umarłych. Według tej mądrości godzi się być dojrzałym, umrzeć się nie godzi ${ }^{22}$.

Nawiązując do przyjmowania sakramentów wiary, jako do przystępowania do źródła, z którego można zaczerpnąć „wody żywej” i napić się, Augustyn wspomina o przyjęciu światła wiary, Bożej nauki, z wszystkimi jej wezwaniami i wymaganiami. Przyjęcie światła, to pozwolenie na to, by Bóg rozświetlił serce i życie człowieka swoją nauką.

„Picie” jest tu utożsamione z przyjęciem światła wiary i stawaniem się nowym człowiekiem. Zestawienie to ma ukazać opozycję do "upijania się" w Dzień Zmartwychwstania, które zamiast otwierać nowe życie i dodawać mądrości, doprowadzało do duchowej śmierci.

O właściwym świętowaniu zagrożonym pijaństwem kaznodzieja mówił:

21 Sermo 226, 1, NBA, 32/1, 384: „Alloquamur istum diem apostolicis verbis. O dies quem fecit Dominus, fuistis aliquando tenebrae: nunc autem lux in Domino. «Fuistis, inquit, aliquando tenebrae». Fuistis, aut non? Recolite facta vestra, si non fuistis. Respicite conscientias vestras, quibus renuntiastis. Quia ergo «fuistis aliquando tenebrae, nunc autem lux», non in vobis, sed «in Domino; sicut filii lucis ambulate»".

22 Sermo 225, 4, 4, NBA, 32/1, 380-382: „Spiritus Dei et potus et lux est. Si invenires fontem in tenebris, lucernam accenderes, ut pervenires ad eum. Noli accendere lucernam ad lucis fontem: ipse tibi lucet, et ad se te ducet. Cum veneris ad bibere, accede et illuminare. "Accedite ad eum, et illuminamini»: nolite recedere, ne contenebremini. Domine Deus, voca, et accedatur ad te: firma, ne recedatur. Fac filios tuos novos, de parvulis senes, sed non de senibus mortuos. In ista enim sapientia senescere licet, mori non licet”. 
Lecz widzicie, bracia, że chcąc świętować te dni cieleśnie, przez intensywne pijaństwo, dopuszczone jakby wielką wolnością, nie jesteście zasługującymi na świętowanie z Aniołami, co oznaczają [te dni] w wieczności. Jeśli bowiem skarcę kogoś mocno pijanego, mówi się: „Ty nauczałeś nas, że te dni oznaczają radość wieczną; ty nam wykazywałeś, że ten czas zapowiada radość anielską i niebieską - nie moglibyśmy więc sobie sprawić dobrą [przyjemność]? Dałby Bóg, aby dobrą, a nie złą. Radość oznacza dla ciebie, że będziesz świątynią Boga. Jeśli zaś nieczystością pijaństwa wypełniłeś świątynię Bożą, mówi Tobie Apostoł: „Ktokolwiek zniszczy świątynię Bożą, tego zniszczy Bóg" (1 Kor 3,17) ${ }^{23}$.

Niekiedy przewrotna ludzka natura popychała wiernych Hippony do szukania argumentów przeciw nauczającemu biskupowi i do prób usprawiedliwiania własnego złego postępowania. Pijaństwo próbowano więc włączać w świętowanie uroczystości religijnych, szczególnie Paschy, Zesłania Ducha Świętego, Nowego Roku ${ }^{24}$ i innych. Argumentując przeciw oponentom, Augustyn wskazywał na dwuznaczność i przewrotność argumentacji. Prawdziwa radość i prawdziwe świętowanie to czynienie z siebie świątyni Boga. Dlatego tym mocniej brzmiały jako przestroga słowa św. Pawła: „Ktokolwiek zniszczy świątynię Bożą, tego zniszczy Bóg” (1 Kor 3,17). Dla Augustyna pijaństwo stanowiło formę zbezczeszczenia Bożej świątyni, wypełnienie jej nieczystością grzechu. Zwłaszcza ci, którzy otworzyli się na Boże działanie, wyznali wiarę, przyjęli sakramenty wiary, winni być wypełnionymi Duchem Świętym a nie winem ${ }^{25}$.

Prawdopodobnie słuchacze Augustyna, powołując się na Księgę Dziejów Apostolskich, widzieli w upijaniu się okazję do zdobycia radości wypływającej z przeżyć religijnych. Biskup dostrzegał te tendencje i próbował je korygować. Wprawdzie zewnętrzne objawy radości wynikającej z zamieszkania $\mathrm{w}$ nich Ducha Świętego mogą być nawet tożsame z upojeniem, co dało się zauważyć także w opisie Dziejów Apostolskich, to jednak jego fundament i przyczyna są zupełnie inne. Napełniony Duchem Świętym śpiewa chwałę Panu, w hymnach

23 Sermo 252, 12, NBA 32/2, 776: „Sed videte, fratres, ne per multam ebriositatem quasi permissi magna effusione, carnaliter volentes celebrare istos dies, non mereamini quod significant in sempiternum cum Angelis celebrare. Forte enim quemcumque ebrium reprehendero, dicturus est: Tu nobis tractasti quia isti dies laetitiam sempiternam significant; tu nobis insinuasti quia hoc tempus gaudium angelicum et coeleste praenuntiat: non ergo debui mecum bene facere? Utinam bene, et non male. Significat enim tibi gaudium, si fueris templum Dei. Si autem immunditia vinolentiae impleas templum Dei, sonat tibi Apostolus: «Quisquis templum Dei corruperit, corrumpet illum Deus» (1 Kor 3,17)".

24 Por. Sermo 198, 1, NBA 32/1, 92.

25 Por. Sermo 225, 4, 4, NBA, t. 32/1, 382. 
i psalmach, i pieśniach duchowych. Źródłem prawdziwej wolności i wiecznej radości jest Bóg - nie wino ${ }^{26}$. I to właśnie na Nim, na Bogu, powinni swoje świętowanie opierać wierzący.

Duch Boży, który jest napojem wierzących, jest jednocześnie i światłem, które w swoim znaczeniu zbliżone jest tu do wiedzy, poznania, mądrości. Dlatego „upojonym” Duchem Świętym towarzyszy również mądrość i roztropność $\mathrm{w}$ ich postępowaniu, które uzupełnia nieopisana radość, przypominająca tylko stan upojenia ${ }^{27}$ - nie należy ono do owoców działania Ducha Świętego, jest wśród nich jednak trzeźwość (por. Gal 5,22-23) ${ }^{28}$.

Słuchacze Augustyna zapewne nie doświadczali tego tak bezpośrednio i szukali podobnych przeżyć. Biskup zauważał więc, że w Dziejach Apostolskich wyraźnie pokazana jest nie tylko sama radość, lecz również i inne nadzwyczajne dary, które otrzymali Apostołowie, w tym dar języków. Pozwalał sobie nawet na ironiczne uwagi pod adresem tych, którzy się upijali:

Człowiek pijany nie uczy się mówić innymi językami, lecz zapomina własnego ${ }^{29}$.

Nadużywanie wina nie ma zatem nic wspólnego z uniesieniami duchowymi opisanymi w Piśmie Świętym, nie przynosi żadnych duchowych czy cielesnych korzyści, sprawia, że człowiek zapomina własnego języka, a więc traci kontakt $\mathrm{z}$ otoczeniem, staje się niezrozumiały, a przez to nieciekawy i odpychający. Pijaństwo nie ma nic wspólnego z prawdziwą radością, wyklucza Boże działanie, gasi Boże „światło” w wierzącym.

\section{Uczty na grobach męczenników}

Jeszcze jako kapłan, w liście do biskupa Aureliusza z Kartaginy, Augustyn zauważał, że szczególnym problemem są uczty urządzane z okazji świąt męczenników albo wspomnień zmarłych. Odbywały się one na grobach, a czasem także w kościołach. Cieszyły się popularnością i wśród większości wiernych nie uchodziły za coś nagannego ${ }^{30}$. Z problemem podobnych zwyczajów zmagano

26 Por. Sermo 225, 4, 4, NBA, t. 32/1, 382.

27 Por. Sermo 225, 4, 4, NBA 32/1, 382.

28 Por Epistula 29, 6, NBA 21, 186-188.

29 Sermo 266, 2, NBA 32/2, 988: „Homo ebrius non alienam linguam discit, sed suam perdit".

30 Por. Epistula 22, 1.2-1.3, NBA 21, 108. Zwyczaj ten wywodził się z rzymskiego święta zmarłych, obchodzonego 21 lutego. Feralia, bo tak je nazywano, było ostatnim dniem 
się także w innych rejonach Kościoła ${ }^{31}$. Wydaje się jednak, że w Afryce Północnej miały one pewien szczególny rys.

\subsection{Praktyka „ucztowania na grobach" w Kościele afrykańskim}

Trudno jednoznacznie ustalić, jak owe praktyki wyglądały w starożytnej Hipponie. Pewnych informacji możemy zaczerpnąć od samego Augustyna, lecz nie znajdziemy u niego dokładnego opisu krytykowanych obchodów. W jednym ze swoich listów pisał:

Po Twoim odjeździe powiadomiono nas, iż ludzie buntują się, twierdząc, że nie mogą znieść zakazu obchodzenia uroczystości, którą nazywają „Radością”. W ten sposób chcą na próżno ukryć prawdziwą jej nazwę, to jest pijaństwo, jak w Twej obecności już nam to mówiono ${ }^{32}$.

Pijackie praktyki w miejscach świętych zostały więc zakazane i to stosunkowo niedawno, patrząc z perspektywy autora. Poza nazwą „laetitiae” przywoływaną przez biskupa dowiadujemy się o niechęci i oporze związanym z zakazem obchodów takich uroczystości ${ }^{33}$. Można przypuszczać, że wywodzący się z pogańskiej tradycji zwyczaj, był ściśle zakorzeniony w obyczajowości Afrykanów.

świąt zwanych paternaliami, obchodzonych ku czci zmarłych, które miały charakter raczej prywatny. Feralia traktowano jako święto publiczne. Na grobach zmarłych składano ofiary Z wina, chleba, orkiszu; por. F. Wodecki, Feralia, EK V 129-130; S. Stabryła, Zarys kultury starożytnej Grecji i Rzymu, s. 183; zob. T. Zieliński, Religia Rzeczypospolitej Rzymskiej, s. $218-248$.

31 O podobnych praktykach wspominał między innymi Bazyli Wielki, krytykując ich związki z pogaństwem: „Pijaństwo, demon dobrowolnie obrany, przez rozkosz do dusz wprowadzony, pijaństwo, macierz złości, przeciwieństwo cnoty, mężnego czyni tchórzliwym, sprawiedliwego rozpustnym, sprawiedliwości nie zna, rozum odbiera. Jak bowiem woda wojuje z ogniem, tak nadmiar wina gasi zdolność myślenia”; Basilius Caesarensis, In ebriosos. Homilia XIV, 2, PG 31, 448; tłum. T. Sinko, s. 144; A. Młotek, Postawy i świadectwa, s. 304-305

32 Epistula 29, 2, NBA 21, 182-184: „Cum post profectionem tuam nobis nuntiatum esset tumultuari homines, et dicere se ferre non posse ut illa solemnitas prohiberetur, quam Laetitiam nominantes, vinolentiae nomen frustra conantur abscondere, sicut etiam te praesente iamiam nuntiabatur", tłum. W. Eborowicz, Pelplin 1991, s. 216.

33 Augustyn przyczynił się do sformalizowania tychże postulatów na synodach w Kartaginie w 397 i 401 r.; por. Synod w Kartaginie (397), kan. 29, tłum. Z. Olejniczak, w: Dokumenty synodów od 381 do 431, s. 79; Synod w Kartaginie (401), kan. 60,tłum. S. Poręba, w: Dokumenty synodów od 381 do 431, s. 136; P.F. Beatrice, Culte chrétien, tłum. M.-A. Vannier, w: Encyclopédie Saint Augustin, s. 420. 
Uczty urządzane w pobliżu grobów należały do tej grupy zwyczajów i zachowań, które stanowiły relikt praktyk pogańskich, niedostatecznie wykorzenionych jeszcze ze świadomości wielu chrześcijan ${ }^{34}$. Początkowo próbowano je schrystianizować $c^{35}$, przyzwalając na pewne ich formy, ale nie zmieniało to samej mentalności wierzących. Paternalia jako obyczaje ludowe oraz feralia jako dzień niegdyś państwowych obchodów ku czci zmarłych były mocno zakorzenione w świadomości prostego ludu ${ }^{36}$.

Zwyczaj ucztowania w miejscach świętych doprowadzał do błędnych przekonań i praktyk, które trudno było wykorzenić. Biskup Hippony pisał:

W przekonaniu nieświadomego ludu, żyjącego zgodnie z zachciankami ciała, pijaństwo i swawolne uczty na cmentarzach nie tylko czczą męczenników, lecz także pocieszają zmarłych ${ }^{37}$.

Wskutek regularnego ponawiania zwyczaje te uchodziły w mentalności wiernych nie tylko za dopuszczalne, lecz także za skuteczne i niosące pomoc zmarłym. Augustyn nie wyjaśniał, jak tę skuteczność rozumieli sami ucztujący, ale wiązała się ona z pewnością z przesłankami pogańskimi.

Podobne powody przyświecały samej częstotliwości praktyk:

Hulanki i pijatyki uchodzą za dozwolone i zalegalizowane do tego stopnia, że dochodzi do nich nie tylko w święta ku czci błogosławionych męczenników, co ktoś, kto niecielesnymi patrzy na to oczyma, nie musi uznać za godne opłakania, lecz odbywają się codziennie ${ }^{38}$.

Uczty ku czci męczenników mogą być oceniane pozytywnie przez mniej zorientowanych religijnie wiernych, co w konsekwencji doprowadza do bagatelizowania problemu. Odbywały się one niekiedy codziennie, choć można przypuszczać, że w tym miejscu Augustyn posuwa się do przesady, a „powtarzające się" tak często uczty miały miejsce jedynie w pewne dni w ciągu roku, być może

34 Por. A. Młotek, Postawy i świadectwa, s. 174.

35 Por. R. Kosiński, Religie Cesarstwa Rzymskiego w V stuleciu, s. 412.

36 Por. T. Zieliński, Religia, s. 227-228.

37 Epistula 22, 1, 6, NBA 21, 110-112: „Sed quoniam istae in coemeteriis ebrietates et luxuriosa convivia, non solum honores martyrum a carnali et imperita plebe credi solent, sed etiam solatia mortuorum”, tłum. W. Eborowicz, s. 180.

38 Epistula 22, 1.3, NBA 21, 106-108: „Comessationes enim et ebrietates ita concessae et licitae putantur, ut in honorem etiam beatissimorum martyrum, non solum per dies solemnes (quod ipsum quis non lugendum videat, qui haec non carnis oculis inspicit), sed etiam quotidie celebrentur", tłum. W. Eborowicz, s. 179. 
właśnie w okolicach dawnego rzymskiego święta zmarłych. Nieraz mogły one przypadać na ostatnie dni przed rozpoczęciem się okresu liturgicznego przygotowania do Paschy. Augustyn wspomina o pojawianiu się tego problemu w podobnych okolicznościach ${ }^{39}$. Trudno jednak stwierdzić, czy głównym motywem urządzania uczt była chęć „przygotowania” bądź „odreagowania” przed zbliżającym się okresem czterdziestu dni postu, czy raczej nawiązanie do pogańskich zwyczajów i tradycji. Być może praktyka życiowa nieświadomie zaczynała łączyć te dwa aspekty, stopniowo zacierając faktyczną ich genezę.

\subsection{Powody wcześniejszej tolerancji}

Swego rodzaju zarzutem, jaki wysuwali chrześcijanie wobec prób zakazywania tego sposobu świętowania, było tolerowanie tej praktyki przez wcześniejszych duszpasterzy ${ }^{40}$. Dlatego Augustyn wyjaśniał:

Aby jednak nie wydawało się, że w jakimkolwiek stopniu obrażamy naszych poprzedników, którzy tolerowali tak jawne wykroczenia niedoświadczonego pospólstwa albo nie ośmielili się ich zakazać, wyłożyłem obecnym, dlaczego moim zdaniem nadużycia takie miały powstać w Kościele. Mianowicie gdy po wielu gwałtownych prześladowaniach nastał pokój, tłumy pogan pragnęły stać się chrześcijanami. Na przeszkodzie temu dążeniu stał fakt, że poganie owi mieli zwyczaj spędzać święta ze swymi bożkami na wystawnych ucztach i pijaństwie, i nie mogliby łatwo powstrzymać się od tych zgubnych wprawdzie, ale z dawną tradycją związanych uciech. Zatem przodkowie nasi postanowili, że tymczasem należy okazać pobłażliwość wobec części tej słabości: pozwolili, aby nowi wyznawcy zamiast porzuconych świąt obchodzili inne uroczystości na cześć świętych męczenników nie wśród dawnego świętokradztwa, lecz przy podobnej wystawności. Wydawało się stosowne, by dopiero ludziom związanym $\mathrm{z}$ imieniem Chrystusa i poddanym jarzmu tak wielkiej powagi przekazać zbawienne przykazania trzeźwości, przeciw którym nie mogliby już oponować ze względu na cześć i szacunek wobec Rozkazodawcy. Zatem nadszedł już czas, by ci, którzy nie śmią zaprzeczyć, że są chrześcijanami, odrzucili ulgi przyznane im kiedyś po to, aby się stali chrześcijanami ${ }^{41}$.

39 Por. Epistula 29, 3, NBA 21, 184. Augustyn wspomina tu o nadejściu „dnia czterdziestnicy (dies quadragesimae)" (tak tłumaczy to W. Eborowicz). Przypuścić należy, że chodzi o dzień rozpoczęcia ówczesnego Wielkiego Postu, czterdziestu dni przez Paschą; por. W. Kamczyk, „Tota paschalis solemnitas”. Teologia i duszpasterstwo w kazaniach i homiliach św. Augustyna, s. 26-27.

40 Por. Epistula 29, 8, NBA 21, 190.

41 Epistula 29, 9, NBA 21, 190-192: „Verumtamen ne illi, qui ante nos tam manifesta imperitae multitudinis crimina vel permiserunt vel prohibere non ausi sunt, aliqua a nobis affici contumelia viderentur, exposui eis qua necessitate ista in Ecclesia viderentur exorta: 
Proces chrystianizacji nie przynosił natychmiastowych efektów, dlatego Augustyn uważał, że należy ze zwyczajem tym postępować ostrożnie, delikatnie, systematycznie jednak rugując go z pobożności chrześcijańskiej. Choć jego poprzednicy i wielu afrykańskich biskupów pozwalało na urządzanie uczt, często związanych z pijaństwem, to celem ich było przyciągnięcie pogan i zwrócenie ich uwagi na Chrystusa. Zamiast czci oddawanej bożkom pogańskim zwracano uwagę na postawy męczenników, którzy oddali za Niego życie. Zmieniał się więc przedmiot kultu, ale forma pozostawała nadal bardzo podobna. Według Augustyna intencją duszpasterzy było jednak stopniowe uświadamianie tych, którzy oddali swoje życie Jezusowi.

\subsection{Potrzeba usunięcia pijackich praktyk}

Porównując pijaństwo z innymi poważnymi wykroczeniami, biskup Hippony wskazywał na zgubne skutki zbytniej frywolności i nieumiarkowania. Nauczał, dlaczego te właśnie postawy nie poruszają tak bardzo sumień wiernych:

Jeżeli ten szpetny sposób postępowania byłby w opinii tylko haniebny, a nie świętokradzki, można byłoby z powodu pobłażliwości mu okazanej go podtrzymać. Wszelako czyż nie mamy tekstu, w którym tenże Apostoł wyliczywszy wiele wykroczeń i wspominając również o pijakach, kończy swą wypowiedź ostrzeżeniem, aby z takimi "nawet chleba nie spożywać" (1 Kor 5,11). Możemy to tolerować w zbytku i wyuzdaniu naszych domowników i towarzyszy ich uczt, jeśli się to odbywa w ścianach prywatnych domów, możemy spożywać ciało Chrystusa z tymi, z którymi Paweł zabrania nam jeść chleb, ale przynajmniej usuńmy tę hańbę z grobów świętych, z miejsc, w których udziela się sakramentów, z domów modlitwy. Bo któż ośmieli się zabronić $\mathrm{w}$ domach prywatnych praktyk, które praktykowane są w świętych miejscach, a zowią się oddawaniem czci męczennikom ${ }^{42}$ ?

scilicet post persecutiones tam multas, tamque vehementes, cum facta pace, turbae Gentilium in christianum nomen venire cupientes hoc impedirentur, quod dies festos cum idolis suis solerent in abundantia epularum et ebrietate consumere, nec facile ab his perniciosissimis et tam vetustissimis voluptatibus se possent abstinere, visum fuisse maioribus nostris, ut huic infirmitatis parti interim parceretur, diesque festos, post eos quos relinquebant, alios in honorem sanctorum martyrum vel non simili sacrilegio, quamvis simili luxu celebrarent: iam Christi nomine colligatis, et tantae auctoritatis iugo subditis salutaria sobrietatis praecepta traderentur, quibus iam propter praecipientis honorem ac timorem resistere non valerent; quocirca iam tempus esse, ut qui non se audent negare christianos, secundum Christi voluntatem vivere incipiant, ut ea quae ut essent christiani concessa sunt, cum christiani sunt, respuantur", tłum. W. Eborowicz, s. 219.

42 Epistula 22, 1.3, NBA 21, 106-108: „Quae foeditas si tantum flagitiosa et non etiam sacrilega esset, quibuscumque tolerantiae viribus sustentandam putaremus. Quanquam ubi 
Przekonanie o usankcjonowaniu pijaństwa we wspomnienia męczenników i nad grobami zmarłych prowadziło do lekceważenia problemu w ogóle. Nie dość, że pozwalało na tolerowanie pijaństwa w domach prywatnych, to jeszcze doprowadzało do desakralizacji świątyni i kultu. Mogło pociągać za sobą kolejne niemoralne praktyki. Nawet jeśli zwyczaj uznawano za haniebny i niegodny, to jednak, w opinii Augustyna, nie dostrzegano jego świętokradczego wymiaru.

Kwalifikując pijaństwo do grzechów związanych ze świętokradztwem (sacrilegia), Augustyn nadawał mu najcięższą rangę grzechu (wspomniane wcześniej „peccata mortifera”), który domagał się podjęcia publicznej pokuty ${ }^{43}$. Powiązanie to pogłębia przypisanie pijaństwu obrazu ciemności, do którego Augustyn nawiązywał często w homiliach paschalnych kierowanych głównie do neofitów. Pijaństwo bowiem niszczyło „świątynię Boga”, którą stali się nowo ochrzczeni w Noc Zmartwychwstania, zgodnie zaś ze słowami św. Pawła: „Jeżeli ktoś niszczy świątynię Boga, tego zniszczy Bóg” (1 Kor 3,17a). Tym samym, grzech ten był bezpośrednim wykluczeniem Boga ze swego życia, swego rodzaju bałwochwalstwem.

Nie mniej istotna dla Augustyna jest kolejność rugowania tychże praktyk z obyczajowości wiernych. Rozpocząć należy od miejsc świętych, grobów męczenników, bo to tam owe praktyki mają swe źródło. Należy usunąć je z miejsc, gdzie udziela się sakramentów świętych, co jest istotnym nawiązaniem do urządzania uczt i pijaństwa z okazji przyjęcia sakramentów wiary. Wreszcie nie powinny mieć one miejsca $\mathrm{w}$ domach modlitwy, bo nie mogą kojarzyć się $\mathrm{z}$ aktami kultu religijnego i z czymś, co jest miłe Bogu. Wtedy też będzie możliwość, by argumentować za rezygnowaniem $\mathrm{z}$ podobnych uczt $\mathrm{w}$ domach prywatnych. $\mathrm{W}$ przeciwnym razie, pijaństwo $\mathrm{w}$ miejscach kultu religijnego będzie zawsze argumentem za powtarzaniem tychże praktyk przez wiernych.

Pragnąc właściwie kształtować wrażliwość wiernych, duszpasterz szukał argumentów, które mogłyby poruszyć serca słuchaczy i jednocześnie zmobilizować i zachęcić do zmiany postaw. W Liście 29 pisał, w jaki sposób próbował to robić:

est illud, quod cum multa vitia enumerasset idem Apostolus, inter quae posuit ebriosos, ita conclusit, ut diceret cum talibus nec panem edere $(1$ Kor 5,11$)$ ? Sed feramus haec in luxu et labe domestica, et eorum conviviorum quae privatis parietibus continentur, accipiamusque cum eis corpus Christi, cum quibus panem edere prohibemur; saltem de sanctorum corporum sepulcris, saltem de locis sacramentorum, de domibus orationum tantum dedecus arceatur. Quis enim audet vetare privatim, quod cum frequentatur in sanctis locis, honor martyrum nominatur?", tłum. W. Eborowicz, s. 179.

43 Por. W. Kamczyk, Perykopa o wskrzeszeniu Łazarza (J 11,1-44) a nauka św. Augustyna o odpuszczeniu grzechów, s. 251. 
Gdy nastąpił dzień Czterdziestnicy i wielki tłum ludzi zgromadził się na kazanie, przeczytano urywek Ewangelii, w którym jest mowa, że Pan wypędził ze świątyni sprzedawców zwierząt, powywracał stoły bankierów (Mt 21,12) i powiedział, że dom Jego Ojca z domu modlitwy stał się jaskinią zbójców (Mt 21,13). Nawiązałem do tego tekstu, kierując uwagę słuchaczy na pijaństwo. Dołączyłem rozważanie, w którym wykazałem, iż o wiele gniewniej i gwałtowniej Pan usunąłby ze świątyni uczty pijackie, które w każdym miejscu są haniebne, skoro w taki sposób usunął ze świątyni dozwolony handel przedmiotami, które wówczas były potrzebne do sprawowania ofiar. Zapytałem ich, co ich zdaniem jest najbardziej podobne do jaskini zbójców: handel potrzebnymi towarami czy nieumiarkowane pijaństwo ${ }^{44}$.

W swej wypowiedzi Augustyn zastosował argument biblijny, nawiązując do sceny wyrzucenia przekupniów ze świątyni. Perykopa ta odczytana została przy okazji „dies quadragesimae” rozpoczynającego okres przygotowań do Paschy. Nieco wcześniej więc mogły odbywać się pijackie uczty związane z pogańskim świętem zmarłych, o czym już wspomniano. Mobilizowany przez biskupa Waleriusza kapłan Augustyn, głosząc homilię, nawiązywał do problemu, powołując się na obraz wyrzuconych ze świątyni przekupniów. Zestawiając Jezusa porównującego handel w świątyni do zachowań mieszkańców jaskini zbójeckiej, z pijackimi ucztami odbywającymi się w miejscach świętych, wyraźnie dawał do zrozumienia, jaka powinna być moralna ocena tego typu postępowania. Nieumiarkowane pijaństwo bardziej przypomina jaskinię zbójców niż wspominany w Biblii handel potrzebnymi towarami. Chrześcijanin, widząc podobne praktyki, powinien raczej upominać, zakazywać, odwodzić od nich, niż szukać w nich przyjemności ${ }^{45}$.

Wagę problemu podkreślił w dalszej części swojego wystąpienia:

A ponieważ miałem przed sobą przygotowane dodatkowe teksty Ewangelii, dodałem, że w owej świątyni, w której nie ofiarowano jeszcze ciała ani krwi Pańskiej,

44 Epistula 29, 3, NBA 21, 184: „Postea vero quam dies Quadragesima illuxisset, et frequens multitudo ad horam tractationis occurrit, lectum est illud in Evangelio, ubi Dominus de templo expulsis venditoribus animalium, et eversis mensis nummulariorum, dixit domum Patris sui pro domo orationum speluncam latronum esse factam (Mt 21,12nn): quod capitulum, cum eos intentos proposito vinolentiae quaestione feci, et ipse quoque recitavi, adiunxique disputationem, qua ostenderem quanto commotius et vehementius Dominus noster ebriosa convivia, quae ubique sunt turpia, de templo expelleret, unde sic expulit concessa commercia, cum ea venderentur, quae sacrificiis illo tempore licitis essent necessaria; quaerens ab eis, quibus similiorem putarent speluncam latronum, necessaria vendentibus, an immoderate bibentibus", tłum. W. Eborowicz, s. 216.

45 Por. In Ioannis Euangelium tractatus 10, 9, s. 570; tłum. W. Szołdrski, W. Kania, PSP 15/1, 165. 
cielesny jeszcze lud żydowski nie ucztował ani po pijanemu, ani nawet na trzeźwo, i nie ma w historii żadnej wzmianki o tym, żeby Żydzi upili się pod pozorem pobożności, z wyjątkiem uroczystości obchodzonej po wykonaniu złotego cielca (por. Wj 32,6). Mówiąc te słowa, wziąłem Pismo Święte i odczytałem całe to opowiadanie. Dodałem z bólem, na jaki mnie było stać, że Apostoł, aby odróżnić lud chrześcijański od zatwardziałości Żydów, napisał list swój nie na tablicach kamiennych, lecz na żywych tablicach serca (2 Kor 3,3). Skoro Mojżesz, sługa Boży, ze względu na owych przywódców robił dwie tablice kamienne (Wj 32,19), dlaczegóż my nie możemy połamać serc tych, którzy będąc ludźmi Nowego Przymierza, chcieli w czasie uroczystości ku czci świętych czynić to, co lud Starego Przymierza zrobił raz, i to na cześć cielca ${ }^{46}$.

Augustyn, przy okazji nawiązywania do tej perykopy, powoływał się na kult w świątyni jerozolimskiej. Lud żydowski, nieznający prawdziwego kultu, nie upijał się w niej pod pozorem pobożności. Jedyny wyjątek stanowiła uroczystość związana z odlaniem złotego cielca, choć wtedy nie miała ona miejsca w świątyni i nie stanowiła oddawania czci prawdziwemu Bogu. Dając za przykład Żydów, którym wielu chrześcijan bywało z zasady niechętnymi, kaznodzieja czynił dość wielki przytyk pod adresem słuchaczy, oto okazywali się oni gorszymi niż nielubiany naród Żydowski. Takie postawienie sprawy mogło stanowić szczególnie mobilizujący, aczkolwiek nieco przewrotny argument.

Przy tej okazji przywołani zostali także dwaj bohaterowie biblijni, reagujący na niewłaściwe zachowania Żydów i chrześcijan - Mojżesz i Paweł Apostoł. Mojżesz, widząc pijaństwo Izraelitów przy okazji oddawania czci złotemu cielcowi, rozbił zapisane Bożym prawem kamienne tablice. Tym bardziej w reakcji na podobne zachowania chrześcijan można i należy rozbijać serca, które stały się, wedle myśli św. Pawła, żywymi tablicami Nowego Prawa i Przymierza z Bogiem. To reakcja biskupa na zachowania powierzonych mu wiernych jest właściwa, a nie smutek tych, którym zabrania się podtrzymywania pijackich

46 Epistula 29, 4, NBA 21, 184-186: „Et quoniam mihi praeparatae lectiones suggerendae tenebantur, adiunxi deinde ipsum adhuc carnalem populum Iudaeorum, in illo templo, ubi nondum corpus et sanguis Domini offerebatur, non solum vinolentia, sed nec sobria quidem unquam celebrasse convivia; nec eos publice religionis nomine inebriatos inveniri in historia, nisi cum festa fabricato idolo exsolverent ( $\mathrm{Wj} 32,6)$. Quae cum dicerem, codicem etiam accepi, et recitavi totum illum locum. Addidi etiam cum dolore quo potui, quoniam Apostolus ait, ad discernendum populum christianum a duritia Iudaeorum, Epistolam suam non in tabulis lapideis scriptam, sed in tabulis cordis carnalibus (2 Kor 3,3), cum Moyses famulus Dei, propter illos principes, binas lapideas tabulas confregisset (Wj 32,19), quomodo non possemus istorum corda confringere, qui homines Novi Testamenti, sanctorum diebus celebrandis ea vellent solemniter exhibere, quae populus Veteris Testamenti et semel et idolo celebravit", tłum. W. Eborowicz, s. 216-217. 
tradycji. Paweł chciał, według Augustyna, odróżnić lud chrześcijański od żydowskiego, a tymczasem wierni Hippony zdawali się, poprzez swoje zachowania i praktyki, być gorsi od Żydów.

Poważnym argumentem w kwestii rugowania konwiwiów mogła być praktyka Kościoła Powszechnego:

Gdyby Afryka usiłowała pierwsza usunąć te nadużycia, powinny by ją naśladować pozostałe kraje. Skoro jednak w większej części Italii i we wszystkich albo prawie wszystkich kościołach zamorskich do występków tych nigdy nie doszło, lub jeśli pojawily się czy utrwaliły, zostały usunięte i wyeliminowane dzięki gorliwości i czujności świętych i prawdziwie zatroskanych o życie wieczne biskupów, [...] to czyż mając przed oczyma tak wspaniały przykład, możemy wahać się z usunięciem tak wielkiej skazy naszych obyczajów ${ }^{47}$ ?

Konwiwia to, w przekonaniu Augustyna, charakterystyczny problem Kościoła afrykańskiego. Przykładem są zwyczaje Kościoła w Italii oraz Kościołów zamorskich, w których podobne ekscesy nie mają miejsca. Choć sam Augustyn zdaje się nie być pewnym, jak w przeszłości wyglądała ta kwestia, to jednak wydaje się przekonany, że zwyczaje te zostały usunięte ${ }^{48}$. Wprawdzie $\mathrm{w}$ innym z listów wspomina o pewnych pijackich praktykach, które incydentalnie pojawiają się w Rzymie, ale wyraźnie daje do zrozumienia, że nie cieszą się one przyzwoleniem duszpasterzy. Augustynowi chodziło o zarzut odbywania się takich praktyk przed bazyliką wzniesioną nad grobem świętego Piotra, oddaloną od siedziby biskupa Rzymu ${ }^{49}$. Tym właśnie faktem, odległością i wielką liczbą obcych - pielgrzymów, tłumaczył dopuszczanie się w tym miejscu owego nad-

47 Epistula 22, 1, 4, NBA 21, 110: „Haec si prima Africa tentaret auferre, a caeteris terris imitatione digna esse deberet: cum vero et per Italiae maximam partem, et in aliis omnibus aut prope omnibus transmarinis Ecclesiis, partim quia nunquam facta sunt, partim quia vel orta vel inveterata, sanctorum et vere de vita futura cogitantium episcoporum diligentia et animadversione exstincta atque deleta sunt, [...] dubitare quomodo possumus tantam morum labem, vel proposito tam lato exemplo emendare?", tłum. W. Eborowicz, s. 179-180.

48 Augustyn wiedział o zakazie wprowadzonym niegdyś w Mediolanie przez biskupa Ambrożego, by nie przynosić posiłków na groby zmarłych. W Kościele tym jednak posiłki te miały raczej charakter bardzo skromny, to w Afryce nabierały podobieństwa do libacji czy też prawdziwych festynów z orkiestrą, a nawet tancerkami. Por. Confessiones VI, 2, CCL 27, s. 74-75; tłum. Z. Kubiak, s. 137-138; A.G. Hamman, Życie codzienne w Afryce Północnej, s. 335.

49 W czasach św. Augustyna rezydencją papieża, biskupa Rzymu, był zespół kościelno-pałacowy położony na Mons Coelius, dawnej posiadłości Lateranów; por. E. Gigilewicz, Lateran, EK X 527. 
użycia ${ }^{50}$. Czasem także wskazywał na zachowania donatystów, którzy kultywowali ten zwyczaj, co też musiało przejmować oburzeniem wiernych Hippony ${ }^{51}$.

Powstrzymanie się od pijaństwa jako elementu kultu religijnego przypisuje duszpasterz trosce „świętych i prawdziwie zatroskanych o życie wieczne biskupów”. Nie jest to więc wymysł duchownych afrykańskich, zamierzających odebrać wiernym resztę życiowych uciech, ale autentycznie prowadzących swoich wiernych ku z góry określonemu celowi.

\subsection{Sposób postępowania ze zwolennikami uczt}

Nie bez znaczenia był również sposób postępowania z tymi, którzy trzymali się dawnych obyczajów:

Lecz to, nad czym dawniej trzeba było ubolewać, teraz należy usunąć, ale nie gwałtem, lecz zgodnie ze słowami Pawła - „w duchu łagodności i łaskawości” (Ga 6,1; 1 Kor 4,21). Twój list zawierający oznaki najbardziej braterskiej miłości ośmiela mnie, abym mówił z Tobą jak sam ze sobą. Wyżej wymienionych nadużyć nie usuwa się - moim zdaniem - ani tonem surowym, ani rozkazującym. Trzeba to uczynić raczej pouczeniem niż rozkazem, raczej ostrzeżeniem niż groźbą. Tak bowiem należy postępować $\mathrm{z}$ tłumem, surowo zaś należy karcić grzech niewielu ludzi. Jeżeli grozimy, wyrażajmy to z bólem, posługując się słowami Pisma Świętego. W ten sposób odwołujemy się do przyszłej kary, aby nie nas się lękano z powodu naszej władzy, lecz Boga, o którym mówimy. Skruszymy w ten sposób najpierw osoby duchowne albo najbliższe duchownym, których autorytet i bardzo usilne upomnienia złamią opór pozostałej reszty ${ }^{52}$.

50 Por. Epistula 29, 10, NBA 21, 192.

51 W niektórych swoich wypowiedziach Augustyn przestawia donatystów jako pijaków, ze względu na częste uczty, odbywane nieraz i w miejscach świętych, przekształcające się nieraz w pijackie orgie. Niekiedy odgłosy tychże obchodów dochodziły nawet do uszu obecnych w katolickiej bazylice wiernych, co musiało przejmować ich niemałym obrzydzeniem, stąd biskup niejeden raz wypominał i krytykował te postawy u donatystów. Por. Epistula 29, 11, NBA 21, 194; In Ioannis Euangelium tractatus 5, 17, s. 330-332; tłum. W. Szołdrski, W. Kania, PSP 15/1, s. 91-92; M.-F. Berrouard, L'ivrognerie des Donatistes, s. 874.

52 Epistula 22, 1, 5, NBA 21, 110: „Sed quod erat tunc dolendum nunc auferendum est; non aspere, sed sicut scriptum est, «in spirito lenitatis et mansuetudinis» (Gal 6,1; 1 Kor 4,21). Dant enim mihi fiduciam litterae tuae indices germanissimae caritatis, ut tecum tanquam mecum audeam colloqui. Non ergo aspere, quantum existimo, non duriter, non modo imperioso ista tolluntur; magis docendo quam iubendo, magis monendo quam minando. Sic enim agendum est cum multitudine: severitas autem exercenda est in peccata paucorum. Et si quid minamur, cum dolore fiat, de Scripturis comminando vindictam futuram ne nos ipsi in nostra potestate, sed Deus in nostro sermone timeatur. Ita prius 
Augustyn wskazuje na sposób postępowania względem najbardziej zatwardziałych zwolenników dawnych zwyczajów. Zaleca za świętym Pawłem postępowanie i napominanie w duchu łagodności i łaskawości. Duszpasterz wie, że w ten właśnie sposób należy postępować z tłumem, który trudno przekonać surowymi nakazami. Najpierw należy zachęcić duchownych i osoby najbliższe ich kręgom. To pomoże w złamaniu oporu reszty.

Wydaje mi się, że będzie łatwiej odwieźć ich od tej obrzydliwej nieobyczajności, jeżeli im się przypomni zakaz Pisma Świętego. A ofiary za dusze zmarłych, które, jak trzeba wierzyć, im pomagają, składane na grobach, nie powinny być wystawne. Należy zezwolić na nie wszystkim proszącym, pod warunkiem, że będą unikać pychy i czynić to szybko. Ponadto przypominamy, że nie wolno tych darów sprzedawać, natomiast jeśli ktoś w pobożnej intencji chciałby ofiarować trochę pieniędzy, to niech natychmiast odda je biednym. W ten sposób nie będzie się wydawało, że lud opuszcza groby swoich bliskich, co byłoby dla nich wielce bolesne. Natomiast będziemy oddawać kult w sposób pobożny i uczciwy w kościele ${ }^{53}$.

Augustyn proponował pewien sposób przeżywania tych uczt, raczej skromny, pokorny, bez chęci zysku, połączony z ewentualnym przekazywaniem darów dla ubogich. Wiernym nie może się wydawać, że opuszczają groby swoich bliskich. Augustyn, przekonany o pomocy, jaką może udzielać Kościół wiernym zmarłym, pragnął wprowadzić pobożność ludową na właściwe tory ${ }^{54}$. Warto zwrócić uwagę, że daje tu jednocześnie świadectwo o wartości „ofiar” składanych za dusze zmarłych. Nie chce, by były to pijackie uczty, ale wspomina o ofiarach dla biednych oraz o skromnej „uczcie”, którą można by odczytać jako aluzję do Eucharystii ${ }^{55}$.

movebuntur spiritales vel spiritalibus proximi, quorum auctoritate, et lenissimis quidem sed instantissimis admonitionibus caetera multitudo frangatur", tłum. W. Eborowicz, s. 180.

53 Epistula 22, 1, 6, NBA 21, 110-112: „Mihi videtur facilius illis dissuaderi posse istam foeditatem ac turpitudinem, si et de Scripturis prohibeatur, et oblationes pro spiritibus dormientium, quas vere aliquid adiuvare credendum est, super ipsas memorias non sint sumptuosae, atque omnibus petentibus sine typho, et cum alacritate praebeantur: neque vendantur; sed si quis, pro religione aliquid pecuniae offerre voluerit, in praesenti pauperibus eroget. Ita nec deserere videbuntur memorias suorum, quod potest gignere non levem cordis dolorem, et id celebrabitur in Ecclesia quod pie et honeste celebratur", tłum. W. Eborowicz, s. 180.

54 Por. A.E. Bernstein, Jak powstawało piekło. Śmierć i zadośćuczynienie, s. 381.

55 W czasach Augustyna uważano za zasadne składanie ofiary Eucharystycznej w intencji zmarłych. Dostrzegano ich wartość na równi z jałmużną. Zwykle łączono je ze śmiercią chrześcijanina, bądź jej rocznicą. Być może Augustyn próbował wprowadzić podobny 
Nie bez znaczenia jest również argument biblijny. W swoich wywodach, przy różnych okazjach, Augustyn powoływał się na słowa i czyny samego Jezusa. Tu warto jeszcze raz wspomnieć perykopę o wyrzuceniu przekupniów ze świątyni (por. Mt 21,12-13) ${ }^{56}$ czy też przykład Jego męki i śmierci na krzyżu (por. Mk 14,67; Mk 15,24; Mt 26,67; Mt 27,35; J 19,5.18) ${ }^{57}$. Niemałe znaczenie miały także słowa św. Pawła, na które powoływał się wielokrotnie: porównanie ludzkiego ciała do świątyni Boga (por. 1 Kor 3,17$)^{58}$, przestroga przed przestawaniem z dopuszczającymi się pijaństwa i innych poważnych grzechów (por. 1 Kor 5,11$)^{59}$, nauka o napełnieniu Duchem Świętym (por. Ef $\left.5,1-19\right)^{60}$, symbolika światła i ciemności (por. Ef 5,8$)^{61}$, kwestia umiarkowania w spożywaniu pokarmów w ogóle (por. Flp 3,19; 1 Kor 6,13; 1 Kor 11,20-22) ${ }^{62}$ i inne. Pojawiają się również aluzje do Starego Testamentu (por. Wj 32,6-19) ${ }^{63}$, zwłaszcza do psalmów (por. Ps 35,9-10; Ps 118,24) ${ }^{64}$. To w Piśmie Świętym widzi kaznodzieja główne źródło chrześcijańskiej nauki, także i w tych okolicznościach.

\section{Podsumowanie}

Podejmując problem pijaństwa, duszpasterz Hippony doskonale zdawał sobie sprawę z sytuacji, w jakich szczególnie dotykał on wiernych. Pewne nawyki i obyczaje, mające swoje źródła w obrzędowości pogańskiej, ciągle jeszcze obecne były jako pożądane w świadomości chrześcijan. Ponieważ wino stanowiło jeden $z$ podstawowych napojów, nie potępia samego picia, ale jego nadużywanie oraz niepożądane łączenie ucztowania z uroczystościami religijnymi. Kwestia ta dotyczyła szczególnie świętowania przyjęcia sakramentów wtajemniczenia w okresie Wielkanocy oraz urządzania uczt na grobach męczenników czy zmarłych, w przekonaniu niesienia im w ten sposób pomocy.

zwyczaj w tym okresie; por. A. Żurek, „Mysterium passionis - corpus et sanguis Christi communio, s. 298-299; A.G. Hamman, Życie codzienne w Afryce Pótnocnej, s. 333.

56 Por. Epistula 29, 3, NBA 21, 184.

57 Por. Epistula 29, 7, NBA 21, 188-190.

58 Por. Sermo 252, 12, NBA 32/2, 766.

59 Por. Epistula 29, 5, NBA 21, 186.

60 Por. Sermo 225, 4, 4, NBA 32/1, 382.

61 Por. Sermo 226, 1, NBA 32/1, 384.

62 Por. Epistula 29, 5, NBA 21, 186; Epistula 29, 11, NBA 21, 194.

63 Por. Epistula 29, 4, NBA 21, 184-186.

64 Por. Sermo 225, 4, 4, NBA 32/1, 382. 
Augustyn, argumentując przeciwko wspomnianym praktykom, posługuje się nauczaniem biblijnym. To w świętych pismach znaleźć można wiele wskazówek dotyczących zła, wynikającego z pijaństwa. Rozbudowuje bogatą symbolikę światła, mądrości i napojenia Duchem Świętym, by otworzyć słuchaczy na właściwe rozumienie działania Bożego i stworzyć podwaliny autentycznie chrześcijańskiego przeżywania radosnych uroczystości. W wykorzenianiu złych przyzwyczajeń nie zalecał radykalizmu, lecz spokojne napominanie. Wskazywał na wartość motywacji przyświecających wiernym i zalecał ukierunkowywanie ich we właściwy sposób. Przykład rozsądnego duszpasterza, troszczącego się o wiernych, będzie z pewnością nadal aktualny i pociągający.

\section{Bibliografia}

\section{Źródła:}

Aurelius Augustinus, Confessionum libri XIII, ed. L. Verheijen, CCL 27, Turnholti 1990; tłum. Z. Kubiak, Warszawa 2006.

Aurelius Augustinus, In Ioannis Euangelium tractati, Bibliothèque Augustinienne, t. 71-75, Paris 1993-2003; tłum. W. Szołdrski, W. Kania, PSP 15, Warszawa 1977.

Aurelius Augustinus, Sermones, NBA 29-35, Roma 1979-2002.

Aurelius Augustinus, Epistulae, NBA 21-23, Roma 1969-1974; tłum. W. Eborowicz, Pelplin 1991; tłum. J. Krzemiński, w: Antologia listu starochrześcijańskiego, t. 1, red. L. Małunowiczówna, Lublin 1978.

Basilius Caesariensis, Homiliae, PG 31, 163-618; tłum. T. Sinko, w: Bazyli Wielki, Wybór homilij i kazań, tł. T. Sinko, Kraków 1947.

Acta synodalia ab anno 381 ad annum 431 (Dokumenty synodów od 381 do 431), red. A. Baron, H. Pietras, Kraków 2010.

Biblia pierwszego Kościoła, tłum. R. Popowski, Warszawa 2016.

\section{Opracowania:}

Bavel T.J. van, Église, tłum. M.-A. Vannier, w: Encyclopédie Saint Augustin. La méditerranée et l'Europe IVe-XXIe siècle, red. A. Fitzgerald, Paris 2005, s. 493-503.

Beatrice P.F., Culte chrétien, tłum. M.-A. Vannier, w: Encyclopédie Saint Augustin. La méditerranée et l'Europe IVe-XXIe siècle, red. A. Fitzgerald, Paris 2005, s. $412-422$.

Bernstein A.E., Jak powstawało piekło. Śmierć i zadośćuczynienie w świecie starożytnym oraz początkach chrześcijaństwa, tłum. A. Piskozub-Piwosz, Kraków 2006.

Berrouard M.-F., L ivrognerie des Donatistes, w: Bibliothèque Augustinienne, t. 71, Paris 1993 , s. 874 . 
Bugaj E., Starożytni Rzymianie i ich uczty, w: Szkice humanistyczne. Wybrane teksty wykładów wygłoszonych na Wydziale Historycznym w ramach Poznańskiego Festiwalu Nauki i Sztuki, red. R. Koliński, A. Kotłowska, I. Barczyńska, K. Polakowski, Poznań 2010, s. 147-163.

Fitzgerald A.G., Pénitence, tłum. C. Broc, w: Encyclopédie Saint Augustin. La méditerranée et l'Europe IVe-XXIe siècle, red. A. Fitzgerald, Paris 2005, s. 1114-1122.

Gigilewicz E., Lateran, EK X 527.

Hamman A.G., Życie codzienne w Afryce Północnej w czasach św. Augustyna, tłum. M. Stafiej-Wróblewska, E. Sieradzińska, Warszawa 1989.

Kamczyk W., Perykopa o wskrzeszeniu Łazarza (J 11, 1-44) a nauka św. Augustyna o odpuszczeniu grzechów, Vox Patrum, 32(2012), t. 57, s. 247-261.

Kamczyk W., „Tota paschalis solemnitas”. Teologia i duszpasterstwo w kazaniach i homiliach św. Augustyna, Katowice 2012 (StAC.SN 12).

Kosiński R., Religie Cesarstwa Rzymskiego w V stuleciu, w: Świat rzymski w V wieku, red. R. Kosiński, K. Twardowska, Kraków 2010, s. 365-416.

La Bonnardière A.M., Pénitence et reconciliation des pénitents d'après saint Augustin II, Revue des Études Augustiniennes 13(1967), s. 249-283.

Młotek A., Postawy i świadectwa. Kościót wobec problemów moralnych IV wieku, Wrocław 1986.

Stabryła S., Zarys kultury starożytnej Grecji i Rzymu, Warszawa 2016.

Staniszewski W., Kościół jako mistyczne Ciało Chrystusa według św. Augustyna, Lublin 1936.

Wodecki F., Feralia, EK V 129-130.

Zieliński T., Religia Rzeczypospolitej Rzymskiej, Toruń 2001.

Żurek A., „Mysterium passionis - corpus et sanguis Christi - communio”. Eucharystia sakramentem wtajemniczenia chrześcijańskiego w Kościele łacińskim czwartego i początku piątego wieku, Katowice 2012 (StAC.SN 14). 